\title{
Comparative prevalence of pathogenic and spoilage microbes in chicken sausages from Egypt and Greece
}

\author{
Samir Mahgoub ${ }^{1,2^{\star}}$, Mahmoud Sitohy $^{3}$ \\ ${ }^{1}$ Microbiology Department, Faculty of Agriculture, Zagazig University, Zagazig, Egypt; \\ *Corresponding Author: mahgoubsamir@gmail.com \\ ${ }^{2}$ Laboratory of Microbiology and Biotechnology of Foods, Department of Food Science and Technology, Agricultural University of \\ Athens, Athens, Greece \\ ${ }^{3}$ Biochemistry Departments, Faculty of Agriculture, Zagazig University, Zagazig, Egypt
}

Received 17 November 2012; revised 18 December 2012; accepted 25 December 2012

\begin{abstract}
This study investigated the spread of foodborne pathogens: Listeria monocytogenes, Escherichia coli 0157:H7, Staphylococcus aureus and Salmonella in chicken sausage samples collected from retail markets in Greece and Egypt during 2006 and from Egypt through 2010. Other microbiological parameters; total viable count (TVC), lactic acid bacteria (LAB), pseudomonads (PS), staphylococci (STAPH), Brochothrix thermosphacta (BT), Enterobacteriaceae (EN), Escherichia coli (EC), yeasts and moulds (Y\&M) were also counted. Egyptian chicken sausage samples were found to harbor $L$. monocytogenes, Staph. aureus and E. coli 0157:H7; with frequencies equivalent to $24 \%, 60 \%$ and $26 \%$ of the total samples during 2006 and $37.87 \%$, $64.44 \%$ and $41.11 \%$ of the total samples during 2010, respectively, while Greek samples were entirely free of theses pathogens. Enrichment techniques indicated the absence of Salmonella from both Greek and Egyptian samples. The obtained results may mobilize food producers and handlers in developing countries to take the due measures reducing food-borne pathogen risks and spoilage flora alongside the poultry chain.
\end{abstract}

Keywords: Chicken Sausage; Food-Borne Pathogens; Contamination; Listeria

\section{INTRODUCTION}

Food safety is of utmost importance all over the world. During food processing, a major risk of contamination may occur directly prior to filling or packaging. So, controlling the microbial load of such products is very cru- cial in ensuring a safe quality end-product. The European Commission regulation on the hygiene of foodstuffs [1] provides a risk-based approach to ensure food hygiene through the implementation of HACCP (hazard analysis and critical control point) procedures. The described measures represent the prerequisite conditions required in food manufacturing facilities [2,3]. Risk management programs including HACCP system is not yet applied in most food processing units and many kinds of traditional foods are still manufactured under somewhat modestly controlled environments especially in the developing countries including Egypt.

Listeria monocytogenes is a food-borne pathogen that can annually cause 2500 cases of meningitis encephalitis, sepsis, fetal death, abortions and about 500 deaths in the United States [4]. Between 1994 and 2002, an enormous amount of chicken and turkey products were recalled because of possible $L$. monocytogenes contamination in United State [5]. Relatively high prevalence of L. monocytogenes in contaminated poultry products has been also reported in Belgium [6], Norway [7] and Northern Ireland [8]. Additionally, a number of poultry products and commercially manufactured foods associated with sporadic cases of listeriosis have been reported [9-12]. Escherichia coli $\mathrm{O} 157: \mathrm{H} 7$ is associated with retail meat products $[13,14]$ and there was a relatively high prevalence of E. coli contaminated poultry products in Slovakia [15]. A more general overview of factors contributing to meat-borne disease outbreaks in England and Wales [16] indicated that inappropriate storage was implicated in $32 \%$ cases, inadequate heat treatment in $26 \%$ cases and cross-contamination (most commonly, raw-to-cooked) in $25 \%$ cases. Cross-contamination during cutting, slicing and packaging of meat products leads to an increase of total viable microorganisms and reduced shelf life [17].

Spoilage of processed meat products prior to the selling date can limit its distribution options inflicting con- 
siderable economic hardships on the manufacturers [18, 19]. At the retail level, meat products are liable to crosscontamination through further handling including slicing into individual parts (e.g. ham, sausages, and pâtés) and packaging. Epidemiological data from Europe, North America, Australia, and New Zealand [20] indicate that substantial proportions of food-borne diseases and spoilage microorganisms can also occur during food preparation practices used in the domestic environment. Several types of psychrotrophic bacteria including Brochothrix thermosphacta, lactic acid bacteria (LAB) and Pseudomonas spp. may grow to levels causing meat spoilage [21].

The aim of the current study was to follow the magnitude of contaminating microflora in the final poultry products collected from retail market of a developing country (Egypt) as compared to a developed one (Greece) to evaluate their liability to contamination by pathogenic and spoilage bacteria in relation to the hygienic status in each case in order to assure or improve the hygienic measures in each case and reach appropriate scientific recommendations. This may mobilize the concerned parties to take the appropriate actions achieving better hygienic measures.

\section{MATERIALS AND METHODS}

\subsection{Sampling Procedure}

Fifty samples of chicken sausages produced by a Greek food manufacturing company were purchased from the retail markets in Athens, Greece one month after their production and one month before their expiry date during 2006. A similar set of samples produced by an Egyptian food manufacturing company was purchased from the retail markets at Cairo Egypt with the same specifications during the years 2006. Other 90 chicken sausage samples produced by three different Egyptian food manufacturing companies were purchased from the retail markets at Cairo, Egypt one month after their production and one month before their expiry date during the year 2010. All samples were transported to the laboratory immediately after collection and stored at $0^{\circ} \mathrm{C}$ until analysis.

\subsection{Bacterial Strains}

Reference strains of L. monocytogenes Scott A, L. innocua FMCC141 and Staph. aureus ATCC6538 were used in this study. All stock cultures were maintained at $-80^{\circ} \mathrm{C}$. Each strain was aseptically sub-cultured in Tryptic Soy broth (TSB) and checked for purity onto Tryptic Soy agar plates (TSA), incubated for $24 \mathrm{~h}$ at $37^{\circ} \mathrm{C}$.

\subsection{Direct Microbiological Counting}

An aliquot (25 g) of each sample was transferred asep- tically to a stomacher bag, combined with $225 \mathrm{ml}$ of sterile Ringer's solution (Lab $100 \mathrm{Z}$ ) and homogenized for $60 \mathrm{~s}$ in a stomacher at room temperature (Lab. Blender 400; Seward Medical, London, UK). The samples were decimally diluted in Ringer's solution and $0.1 \mathrm{ml}$ from duplicate samples of appropriate dilutions were spread onto the surface of solid media. Determinations were carried out as follows: total viable counts (TVC) on Plate Count agar (PCA, Merck, 1.05463 ) incubated at $30^{\circ} \mathrm{C}$ for $72 \mathrm{~h}$; yeasts and moulds on Rose Bengal Chloramphenicol Agar (Lab M 36, supplemented with chloramphenicol, $\mathrm{X} 009$ ) incubated at $25^{\circ} \mathrm{C}$ for 5 days; pseudomonads on Pseudomonas agar Base (Lab M, supplemented with Cetrimide-Fucidin-Cephaloridene, X109) incubated at $25^{\circ} \mathrm{C}$ for $48 \mathrm{~h} ;$ B. thermosphacta on Streptomycin Thallous Acetate Actidione agar (Oxoid M0881, supplemented with streptomycin sulphate, thallous acetate and cycloheximide SR0151) incubated at $30^{\circ} \mathrm{C}$ for $72 \mathrm{~h}$; staphylococci on Baird Parker agar (Biolife, 401116 supplemented with egg yolk) incubated at $37^{\circ} \mathrm{C}$ for $48 \mathrm{~h}$. $E$. coli on Harlequin Tryptone Bile X-Glucuronide agar (TBX) (LAB HAL003) incubated at $44^{\circ} \mathrm{C}$ for $24 \mathrm{~h}$. Particularly, E. coli $\mathrm{O} 157: \mathrm{H} 7$ on TBX agar incubated at $37^{\circ} \mathrm{C}$ for $4 \mathrm{~h}$ then incubated at $44^{\circ} \mathrm{C}$ for $37 \mathrm{~h}$. Listeria spp. was enumerated on Polymyxin-Acriflavin-Lithium Chloride-Ceftazidime-Aesculin-Mannitol agar (PALCAM, Biolife 401604) after incubation for $48 \mathrm{~h}$ at $35^{\circ} \mathrm{C}$. Salmonella was counted on Xylose Lysine Deoxycholate agar (XLD) (Merck, 1.05287) after incubation for $24 \mathrm{~h}$ at $37^{\circ} \mathrm{C}$. For Lactic acid bacteria (LAB) and Enterobacteriaceae enumerations, $1 \mathrm{ml}$ sample was inoculated into 10 $\mathrm{ml}$ of molten de Man Rogosa Sharpe agar (MRS, Biolife 401728) and Violet Red Bile Dextrose Agar (Biolife 402188). After setting, a $10 \mathrm{ml}$ overlay of the same molten medium was added. The incubation was carried out at $25^{\circ} \mathrm{C}$ for $72 \mathrm{~h}$ and at $37^{\circ} \mathrm{C}$ for $24 \mathrm{~h}$, respectively. All plates were examined for typical colony types and morphological characteristics associated to each culture medium. S. aureus colonies were further tested for positive coagulase reaction (Bactident Coagulase Biolife).

\subsection{Post Enrichment Pathogenic Detection}

A two-stage enrichment procedure was used for the detection and isolation of Listeria spp. according to ISO 11290 [22]. An amount of each sample (25 g) was added to Half Fraser broth $(225 \mathrm{ml})$ and incubated at $30^{\circ} \mathrm{C}$ for $24 \mathrm{~h}$. Then an aliquot $(0.1 \mathrm{ml})$ of the primary enrichment media was transferred to a tube containing $10 \mathrm{ml}$ of a secondary enrichment medium (Frazer broth) and incubated for $48 \mathrm{~h}$ at $35^{\circ} \mathrm{C}-37^{\circ} \mathrm{C}$. Aliquots from both media were inoculated into PALCAM dishes and incubated at $35^{\circ} \mathrm{C}$ for $48 \mathrm{~h}$. Presumptive colonies were subcultured on tryptone soya agar (Lab. M) and incubated for $24 \mathrm{~h}$ at $35^{\circ} \mathrm{C}$. Simplified genus identification was conducted 
using Gram stain, catalase and oxidase reactions, motility at $25^{\circ} \mathrm{C}, \beta$-haemolysis reaction, and biochemical identification by fermentation of D-xylose, L-rhamnose, $\alpha$ methyl-D-mannoside and D-mannitol [23]. To identify several fastidious strains, API-Listeria Kit was used. For E. coli $\mathrm{O} 157: \mathrm{H} 7$, the samples were analyzed using the method described in ISO 16654 [24]. Aliquots of the samples $(25 \mathrm{~g})$ were added to $225 \mathrm{ml}$ volumes of modified tryptone soy broth with novobiocin (Merck) and incubated at $41.5^{\circ} \mathrm{C}$ for $18-24 \mathrm{~h}$. Following incubation, $0.1 \mathrm{ml}$ of each enrichment sample was transferred onto Tryptone Bile Glucuronide (TBX) agar and incubated at $37^{\circ} \mathrm{C}$ for $4 \mathrm{~h}$, then subsequently at $44^{\circ} \mathrm{C}$ for $20 \mathrm{~h}$.

The detection of Salmonella spp. was achieved by ISO 6579 [25] by suspending $25 \mathrm{~g}$ of the product into $225 \mathrm{ml}$ buffered peptone water (BPW) (Merck), and incubating at $37^{\circ} \mathrm{C}$ for $20 \mathrm{~h}$. Then, $0.1 \mathrm{ml}$ of each BPW medium was transferred into a culture tube containing $10 \mathrm{ml}$ of Rappaport Vassiliadis (RV) enrichment broth and incubated again at $42^{\circ} \mathrm{C}$ for $24 \mathrm{~h}$. From both steps, a portion of the sample was streaked on XLD agar (Merck, 1.05287) and incubated at $37^{\circ} \mathrm{C}$ for $24 \mathrm{~h}$.

\subsection{Statistical Analyses}

Data from microbiological analyses were entered into Excel and transformed to $\log _{10}$ values. All presented values are the averages of three replicates plus the standard deviation.

\section{RESULTS AND DISCUSSIONS}

\subsection{The Overall Distribution of Microbial Group}

The data in Figure 1 delineate the overall distribution of different microbial groups in 100 chicken sausages samples collected from the retail markets in each of Egypt and Greece one month after the date of their production during the year 2006. The number of samples positive to any microbial was related to the total tested samples giving the relative overall distribution. The total viable count (TVC) and lactic acid bacteria (LAB) were counted and detected in 100\% of Egyptian samples while in only $68 \%$ and $62 \%$ of Greek samples, respectively. All other tested microbial groups were detected by direct counting or enrichment techniques in Egyptian samples where the most spread microbial groups were $B$. thermosphacta (BT), Enterobacteriaceae (EN), staphylococci (STAPH), yeasts \& moulds (Y\&M) and pseudomonads (PS) being distributed in 100, 96, 92, 82 and $82 \%$ of the tested samples, respectively. Greece samples were only positive for few microbial groups, i.e. BT, Y\&M and PS accounting for $20 \%, 12 \%$ and $6 \%$ relative distribution in the tested samples, respectively. Other groups were totally absent by enrichment techniques in Greek samples. Enrichment technique did not reveal any Salmonella in either Egyptian or Greek samples. In Brazil, Salmonella was not isolated from chicken sausage [26]. Therefore, the plant environment, packaging and chill storage may be unfavorable to its persistence and growth. This finding is similar to the results of Yilmaz et al. [27] on Turkey chicken sausage showing no recovery of E. coli, Staph. aureus and Salmonella spp. The presence of L. monocytogenes and Salmonella spp. were not detected in any of the ready to eat meat in Greece [28].

\subsection{Relative Distribution of Spoilage Microbes}

Figure 2 shows the relative distribution of TVC, LAB,

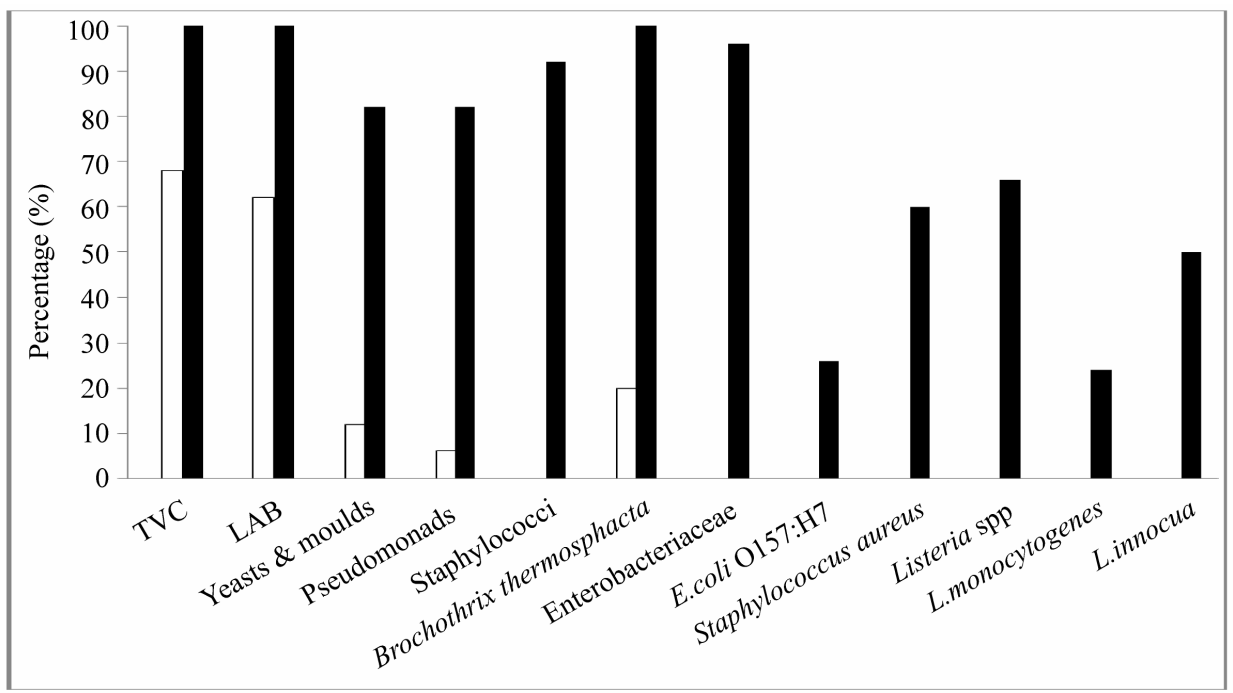

Figure 1. Relative quantitative distribution of spoilage microbes in chicken sausage collected from Egypt (black columns) and Greece (white columns) during the year (2006). 

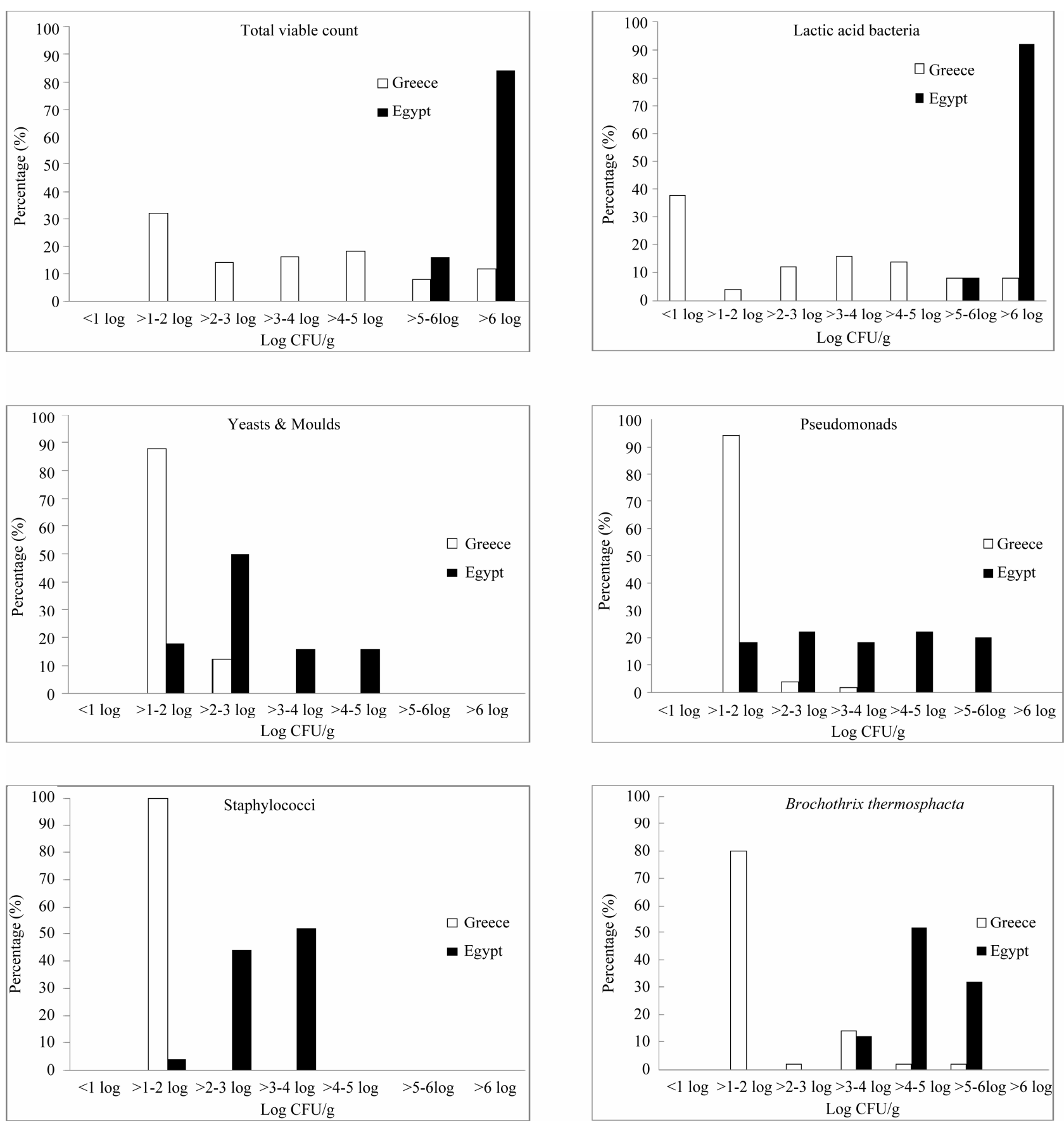

Figure 2. Relative quantitative distribution of indicator and pathogenic bacteria in chicken sausage from Egypt and Greece during the year 2006.

Y\&M, PS BT and STAPH in chicken sausage samples collected from Greece and Egypt. Sausage samples were categorized into 7 levels according to the microbial load; $<1,>1-2,>2-3,>3-4,>4-5,>5-6,>6 \log \mathrm{CFU} / \mathrm{g}$. The relative distribution of any microbe was calculated by dividing the number of the samples within certain level by the number of the total samples and multiplying by 100 . Egyptian samples were most distributed in the high TVC load category ( $>6 \log \mathrm{CFU} / \mathrm{g}$ ) recording 84\% of the total. The other $16 \%$ were distributed in the second highest level of bacterial load ( $>5-6 \log \mathrm{CFU} / \mathrm{g}$ ). On the other hand the TVC in Greek samples followed nearly a normal distribution pattern, except that the highest distribution $(32 \%)$ was recorded in the lowest bacterial load level $(<2 \log \mathrm{CFU} / \mathrm{g})$. The same trend of quantitative distribution in both Egyptian and Greek samples was also true for LAB except that the highest bacterial load level ( $>6 \log \mathrm{CFU} / \mathrm{g})$ was spread in about $92 \%$ of the 
total Egyptian samples while the lowest bacterial load level in Greek samples was spread in about $38 \%$ of the total Greek samples. Since the level $>6 \log \mathrm{CFU} / \mathrm{g}$ is the maximal permissible level for the aerobic plate count in meat products [29] about $92 \%$ of Egyptian samples can be classified as unacceptable for human consumption. Previous studies on chicken products, such as chicken sausage from Egypt have reported that the total bacteria count ranged from 7 to $8 \log \mathrm{CFU} / \mathrm{g}[30,31]$. In Spain, chicken sausage had total bacterial counts of mesophiles and psychrotrophs from 7.14 to 7.28 and 7.72 to $7.87 \mathrm{log}$ CFU/g, respectively and about $80 \%$ of the chicken sausage were regarded unacceptable [32]. In contrast, in USA, [33] found the aerobic plate count of chicken sausage was in the level $4.65 \log$ CFU/g. Thus, the product's microbial load depends largely on the geographical location, the associated environmental and hygienic status. However, factors such as handling, processing, packaging, storage and display may influence the microbiological load of food products at the sale points [34].

Yeasts and moulds in Egyptian samples followed the normal distribution pattern, indicating the highest distribution at the medium level $(>2-3 \log$ CFU/g). Greek samples distribution deviated towards the lowest detection limit $(<2 \log$ CFU/g) which recording $88 \%$ distribution of the total. This trend was also applied for the quantitative distribution of pseudomonads group in the samples of the two countries. The distribution of staphylococci group in the Egyptian samples was centered in the medium level $(>2-3 \log$ and $3-4 \log \mathrm{CFU} / \mathrm{g})$ achieving $44 \%$ and $52 \%$ distribution of the total samples, respectively, while all Greek samples were under the detection limit. The distribution of BT was exclusively condensed between the medium and high limit $(>3-6$ $\log \mathrm{CFU} / \mathrm{g}$ ) in Egyptian samples while it was located in the low detection level $(80 \%)$ in all Greek samples. The $\mathrm{pH}$ values of chicken sausage were $6.25-6.38$ and 6.33 6.87 in the samples from Egypt and Greece, respectively, i.e. the $\mathrm{pH}$ of Egyptian samples was relatively lower, compared to Greek samples.

\subsection{Relative Distribution of Pathogenic Microbes}

Figure 3 shows the relative distribution of EN and bacterial pathogens (E. coli O157:H7, Staph. aureus, Listeria spp., L. monocytogenes and L. innocua) in chicken sausage from Egypt and Greece. The relative quantitative distribution of EN in Egyptian samples followed nearly the normal distribution pattern while all Greece samples were under the detection level. The presence of EN in processed food may give a strong indication of inadequate treatment or environmental post-process contamination, and may also indicate the extent of faecal contamination. The distribution of the pathogenic bacteria $(E$. coli O157:H7, Staph. Aureus and Listeria spp., L. monocytogenes and L. innocua) seems concentrated in the lowest two levels ( $>1-2$ to $>2-3 \log$ CFU/g) in Egyptian samples while all Greek samples were totally under the detection limit (>1 - $2 \log$ CFU/g). Nørrung et al. [35] recommended zero tolerance for $L$. monocytogenes in 25 $\mathrm{g}$ of ready to eat meat products when the shelf life is longer than a week, but when shorter, the tolerance level could be $<100 \mathrm{CFU} / \mathrm{g}$, so the level $2-3 \operatorname{logs} \mathrm{CFU} / \mathrm{g}$ at sale points may represent a potential risk to health. Counts of this level may also indicate a significant failure of hygienic standards in the preparation and storage of sausage. Additional, problems due to the growth of pathogenic bacteria in sausages such as L. monocytogenes may cause serious food safety problems for consumers. All Greece samples were under the lowest pathogenic detection limit in contrast to $30 \%-75 \%$ of Egyptian samples, which were in that level. That may imply that $25 \%-70 \%$ of the Egyptian samples harbored pathogens at a medium bacterial load of $>2-3 \log$ $\mathrm{CFU} / \mathrm{g}$. The most common pathogens associated with meat products are L. monocytogenes, E. coli $\mathrm{O} 157: \mathrm{H} 7$, Staph. aureus and Salmonella [36,37]. The production process of cooked meats includes a heating step that is probably sufficient to eliminate any $L$. monocytogenes and other present pathogens, so its presence in the tested samples is most likely due to post-process contamination [38]. Additionally, the ubiquitous presence of Listeria spp. in the environment and poor handling can lead to their spread in food-processing environments and the food chain. Taking into account that storage conditions may allow for rapid growth of pathogen [39], its presence in processed meat products could pose serious health problems. Noack and Jockel [40] reported that between 1990 and 1992, official testing of 1235 samples of meat and meat products yielded $L$. monocytogenes in $3.7 \%$ of cooked sausage. Listeria spp. including $L$. monocytogenes was isolated from chicken meat products [12,41]. L.monocytogenes was detected in $8.8 \%$ cooked meat products in Northern Spain [39], 18\% of retail chicken in Northern Ireland [8], 38\% in Belgium [6] and $37 \%$ in Japan [42]. Moreover, L. monocytogenes was a contaminant in slaughterhouses and poultry processing plants [43]. Previous studies on chicken sausage in Spain [33] and chicken frankfurter sausage in Egypt [30] have reported incidences of $S$. aureus of $100 \%$ and $40 \%$, respectively. The levels of this pathogen in chicken frankfurter sausage from Egypt are similar to those re- ported by [32] in chicken sausage, with average of $3.15-3.23$ $\log$ CFU/g. The presence of Staph. aureus in meat products may arise from food handlers through packaging and storage of the product at high temperature [44-46]. The presence and the number of E. coli in food are important as indicators of cross-contamination [47]. It has been suggested that several factors may contribute to the 

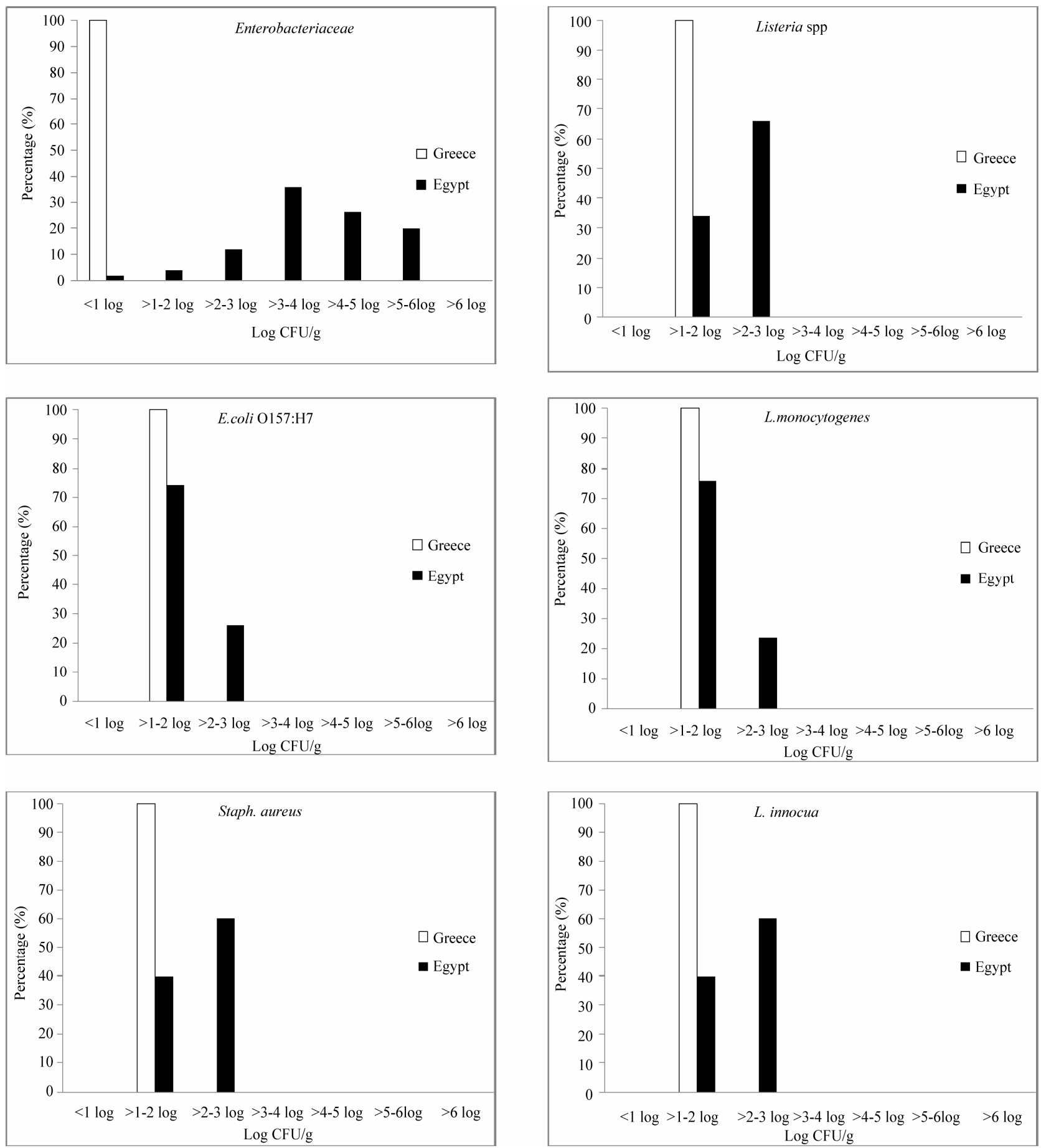

Figure 3. Relative total microbial distribution in chicken sausages from Egypt and Greece during the year 2006.

presence of these pathogens, including poor handling, poor hygiene practices, cross-contamination from food handlers and storage conditions [46]. Chicken sausage samples from Spain were reported to contain $E$. coli groups range from 3.48 to $4 \log \mathrm{CFU} / \mathrm{g}$ [32]. Taulo et al. [48] found positive correlation $(p<0.05)$ between the presence of E. coli and Staph. aureus in food samples. Several authors found that E. coli O157:H7 was associ- ated with derived retail meat products $[13,14]$. Of the 1750 ground beef samples analyzed, $20(1.1 \%)$ of these were positive for E. coli O157 [49].

\subsection{Absolute Microbial Counts of Spoilage and Pathogenic Microbes}

Figure 4 shows that the microbial counts in chicken 

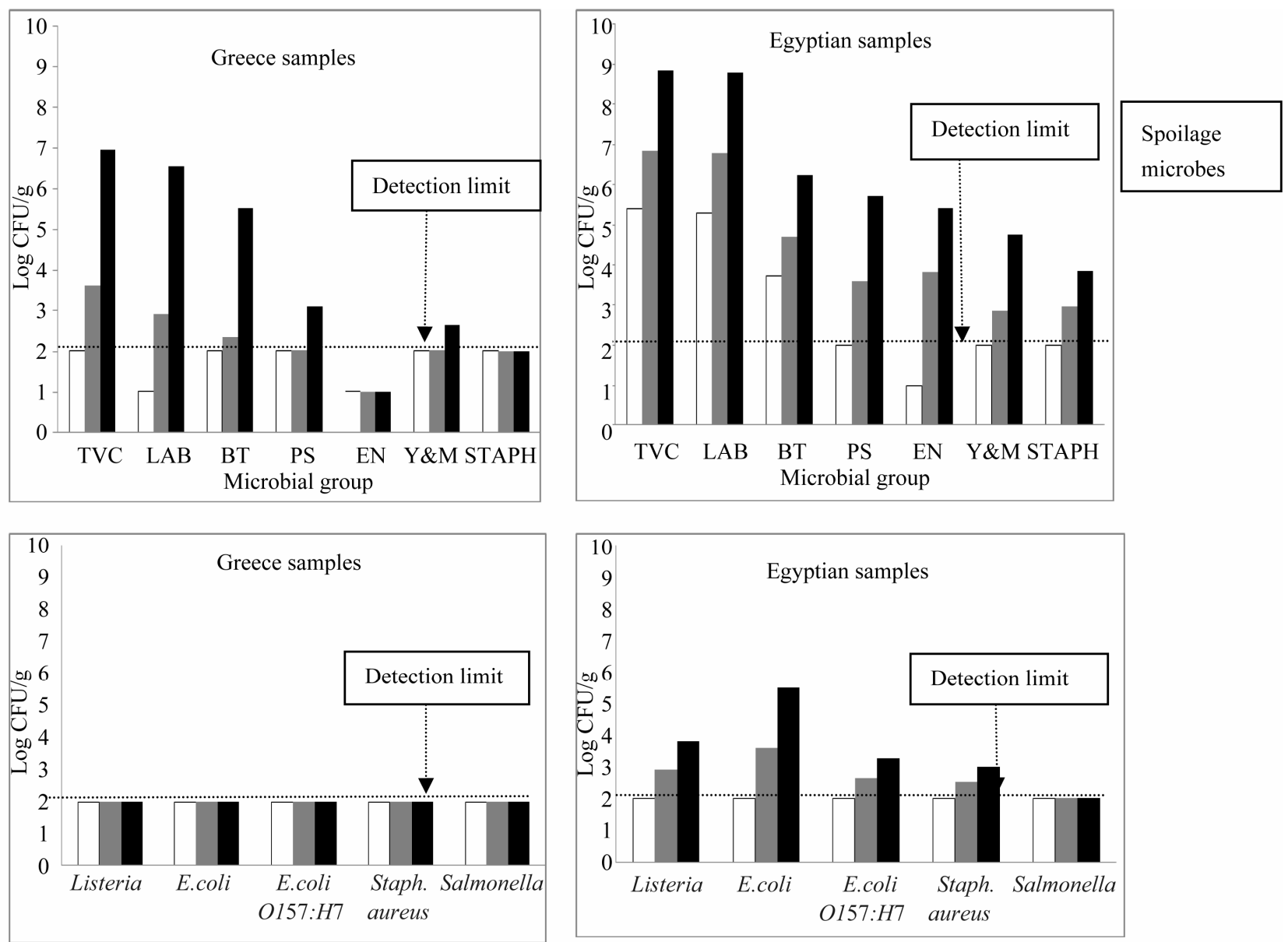

Figure 4. Microbial counts (TVC, total viable count; LAB, lactic acid bacteria; BT, Brochothrix thermosphacta; PS, pseudomonads; EN, Enterobacteriaceae; Y\&M, yeasts and moulds; STAPH, staphylococci) in chicken sausage from Greece and Egypt (black columns $=$ the maximum, gray columns $=$ the average and white columns $=$ the minimum) during the year 2006.

sausage from Egypt and Greece as characterized by maximum and minimum as well as the average of the whole samples. It can generally be observed that the maximum levels of the different spoilage microbes were higher in Egyptian samples than in Greek samples. The maximum values of all Egyptian samples were over the detection limit, compared to only 5 groups in Greek samples. All minimum levels in Greek samples were under the detection limit, while there were three microbial groups in Egyptian samples whose minimum were over the detection limit. The average values of the microbial groups in Greek samples were either below the detection limit (4 groups) or slightly over the detection limit (3 groups) but in all Egyptian samples the averages of all microbial groups were evidently over the detection limit. All these results indicate a more hygienic and safety correlated conditions during production and distribution of Greek sausages. The distribution of pathogenic microbial groups shows that, maximum, minimum and average values were all under the detection limit for Greek samples while most of Egyptian samples (4 out of 5) had the maximum and average levels over the detection limit, particularly Listeria spp., E. coli O157:H7 and Staph. aureus. So these three groups may represent pathogenic hazards in Egyptian samples. Salmonella level was under the detection limit and hence does not pose hygienic problem. The presence of low number of microorganisms in chicken sausages from Greece, may be a synergistic result of quality of raw materials, ingredients, cooking, vacuum packaging and chill storage as well as good hygienic quality and practices. In addition to microbiological quality of the products, factors such as handling, processing, packaging, storage and delivery may also influence the microbiological load of food products at the point of sale [34].

\subsection{Pathogenicity of Listeria Isolates Collected from Egyptian Samples}

Listeria isolates were subjected to haemolytic test on blood agar to disclose their pathogenicity. In control samples (Figure 5), L. monocytogenes ScottA (B) in- 
duced a clear zone on blood agar indicating haemolysis while L. innocua (C) does not. Staph. aureus (A) normally induces a clear zone on the outer border of the growth (colony). 34 isolates producing clear zones similar to L. monocytogenes Scott A and 36 isolates producing zones corresponding to L. innocua. From the 70 examined Listeria isolates could be separated into 34 pathogenic L. monocytogenes and $36 \mathrm{~L}$. innocua. This is quite an alarming result revealing the hazardous hygienic status of Egyptian sausage samples while Greek sausage samples were safe. None of the samples produced zones comparable to that of the Staph. aureus. The 34 pathogenic L. monocytogenes isolated from 12 Egyptian sausage samples, i.e. they were distributed in about $24 \%$ of the total samples. Sporadic cases of listeriosis have been reported in a number of poultry products [9-12].

Following the magnitude of contaminating microflora in the final poultry products collected from retail market of a developing country (Egypt) as compared to a developed one (Greece), could evaluate the bacteriological quality and estimate the hygienic status in every case in order to improve the hygienic measures and motivate concerned parties to take the appropriate actions achieving this objective.

\subsection{Comparative Prevalence of Pathogenic Bacteria in Chicken Sausages from Egypt during 2006 and 2010}

L. monocytogenes, E. coli O157:H7 and Staph. aureus were detected in chicken sausages produced by three food manufacturing companies (B, C and D) in Egypt during 2010 and compared by food manufacturing company (A) during 2006 (Table 1). L. monocytogenes, E. coli O157: H7 and Staph. aureus were detected in about 24\%, 26\% and $60 \%$ of the samples of the producing company A from Egypt during the year 2006 compared to respective values of $37.78 \%, 41.11 \%$ and $64.44 \%$ of the samples of the producing companies B, C and D from Egypt dur- ing the year 2010. This indicates clearly that the microbial pathogens are highly prevalent in Egypt and there was no improvement in the general hygienic status between 2006 and 2010, due probably to the insufficiency of the means and measures required for microbial control. Generally, the same trend found in 2006 applied also to the samples collected in 2010, irrespective of the producing company. This result reveals that the hygienic status was still very poor and no serious actions were taken to improve it.

\section{CONCLUSION}

The samples of chicken sausage from Egypt collected

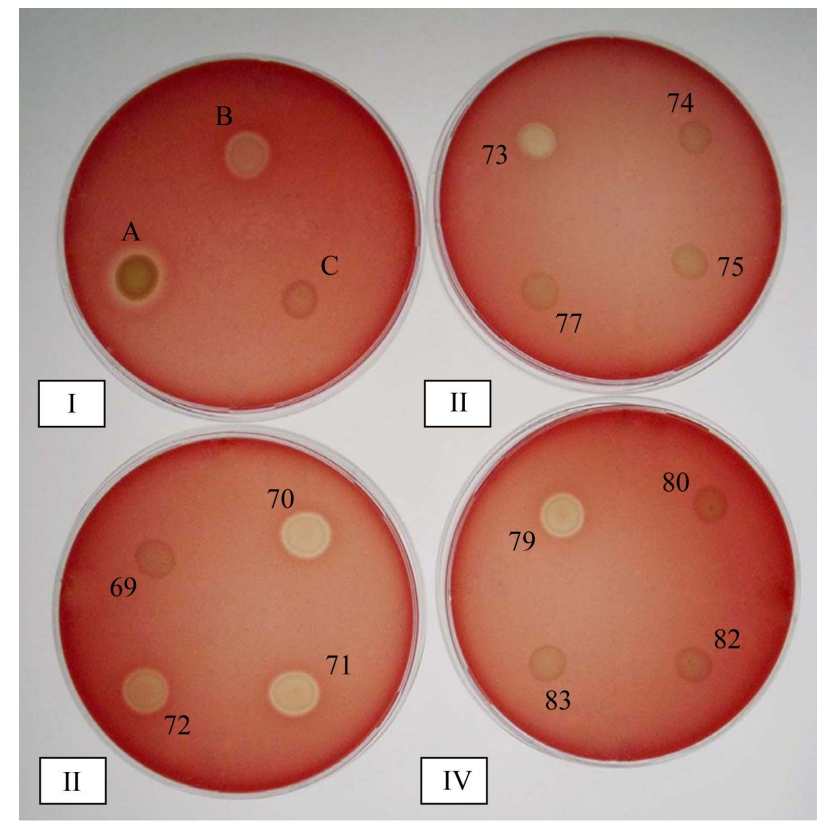

Figure 5. Heamolytic activity of some L. monocytogenes isolates collected from Egyptian sausage samples during 2006 and 2010. The control plate (I) contain Staph. aureus (A), L. monocytogenes (B) and L. innocua (C) and the other plates (II-IV) contain random samples.

Table 1. The prevalence of Salmonella, L. monocytogenes, E. coli O157:H7 and Staph. aureus in chicken sausages from Egypt during 2006 and 2010.

\begin{tabular}{|c|c|c|c|c|}
\hline $\begin{array}{l}\text { Company and number of } \\
\text { samples }\end{array}$ & Salmonella & L. monocytogenes & E. coli $\mathrm{O} 157: \mathrm{H} 7$ & Staph. aureus \\
\hline \multirow{3}{*}{$\mathrm{A}(50)$} & \multicolumn{4}{|c|}{ No. of positive samples during 2006} \\
\hline & ND & $12(24.00 \%)$ & $13(26.00 \%)$ & $30(60.00 \%)$ \\
\hline & \multicolumn{4}{|c|}{ No. of positive samples during 2010} \\
\hline $\mathrm{B}(30)$ & ND & $12(40.00 \%)$ & $10(33.33 \%)$ & $15(50.00 \%)$ \\
\hline $\mathrm{C}(30)$ & ND & $13(43.33 \%)$ & $15(50.00 \%)$ & $21(70.00 \%)$ \\
\hline $\mathrm{D}(30)$ & ND & $9(30.00 \%)$ & $12(40.00 \%)$ & $22(73.33 \%)$ \\
\hline Total (90) & ND & $34(37.78 \%)$ & $37(41.11 \%)$ & $58(64.44 \%)$ \\
\hline
\end{tabular}

ND, not detected. 
in 2006 were found to harbor Listeria spp., Staph. aureus and E. coli $\mathrm{O} 157: \mathrm{H7}$, while these pathogens were not detected in Greek samples. The pathogenic L. monocytogenes was exclusively detected in $24 \%$ and $37.78 \%$ of the total Egyptian samples during 2006 and 2010, respectively. While Salmonella was absent in both Greek and Egyptian samples as revealed by enrichment techniques. The prevalence of pathogenic bacteria in Egyptian samples was confirmed after 4 years from the original study. The obtained results will mobilize the concerned parties to take the necessary measures reducing food-borne pathogen risks and spoilage flora alongside the poultry chain.

\section{ACKNOWLEDGEMENTS}

This research was supported by the Laboratory of Food Microbiology and Biotechnology, Department of Food Science and Technology, Agricultural University of Athens, Greece and Greek Scholarship Foundation (IKY), Greece. We would like to express our deep thanks to Prof. George-John Nychas and all colleagues in the Laboratory for supporting me during this study.

\section{REFERENCES}

[1] European Commission Regulation (EC) (2004) No. 852/ 2004 of the European Parliament and of the Council of 29 April 2004 on the hygiene of foodstuffs. Official Journal of the European Union, 139, 1-54.

[2] CAC (Codex Alimentarius Commission) (1997) Recommended international code of practice general principles of food hygiene. CAC/ RCP 1-1969, Rev 3 Food and Agriculture Organization of the United Nations World Health Organization, Rome.

[3] CAC (Codex Alimentarius Commission) (2010) ThirtyThird Session International Conference Centre, Geneva. www.codexalimentarius.net

[4] Mead, P.S., Slutsker, L., Dietz, V., McCaig, L.F., Bresee, J.S., Shapiro, C., Grifn, P.M. and Tauxe, R.V. (1999) Foodrelated illness and death in the United States. Emerging Infectious Diseases, 5, 607-625. doi:10.3201/eid0505.990502

[5] Teratanavat, R. and Hooker, N.H. (2004) Understanding the characteristics of US meat and poultry recalls: 19942002. Food Control, 15, 359-367. doi:10.1016/S0956-7135(03)00098-7

[6] Uyttendaele, M., De Troy, D. and Debevere, J. (1999) Incidence of Listeria monocytogenes in different types of meat products on the Belgian retail market. International Journal of Food Microbiology, 53, 75-80. doi:10.1016/S0168-1605(99)00155-5

[7] Rørvik, L.M., Aase, B., Alvestad, T. and Caugant, D.A. (2003) Molecular epidemiological survey of Listeria monocytogenes in broilers and poultry products. Journal of Applied Microbiology, 94, 633-640. doi:10.1046/j.1365-2672.2003.01895.x
[8] Soultos, N., Koidis, P. and Madden, R.H. (2003) Presence of Listeria and Salmonella spp. in retail chicken in Northern Ireland. Letters in Applied Microbiology, 37, 421-423. doi:10.1046/j.1472-765X.2003.01423.x

[9] Farber, J.M. and Peterkin, P.I. (1991) Listeria monocytogenes, a food-borne pathogen. Microbiology Reviews, 55, 476-511.

[10] Rocourt, J., BenEmbarak, P., Toyofuku, H. and Schlundt, J. (2003) Quantitative risk assessment of Listeria monocytogenes in ready-to-eat foods: The FAO/WHO approach. FEMS Immunology and Medical Microbiology, 35, 263267. doi:10.1016/S0928-8244(02)00468-6

[11] McLauchlin, J., Mitchell, R.T., Smerdon, W.J. and Jewell, K. (2004) Listeria monocytogenes and listeriosis: A review of hazard characterisation for use in microbiological risk assessment of foods. International Journal of Food Microbiology, 92, 15-33. doi:10.1016/S0168-1605(03)00326-X

[12] Little, C.L., Barrett, N.J., Grant, K. and McLauchlin, J. (2008) Microbiological safety of sandwiches from hospitals and other health care establishments in the United Kingdom with a focus on Listeria monocytogenes and other Listeria species. Journal of Food Protection, 71, 309-318.

[13] Chapman, P.A., Malo, A.T.C., Ellin, M., Ashton, R. and Harkin, M.A. (2001) Escherichia coli $\mathrm{O} 157$ in cattle and sheep at slaughter, on beef and lamb carcasses and in raw beef and lamb products in South Yorkshire, UK. International Journal of Food Microbiology, 64, 139-150. doi:10.1016/S0168-1605(00)00453-0

[14] Chinen, I., Tanaro, J.D., Miliwebsky, E., Lound, L.H., Illemi, G., Ledri, S., et al. (2001) Isolation and characterization of Escherichia coli O157:H7 from retail meats in Argentina. Journal of Food Protection, 64, 1346-1351.

[15] Pilipčinec, E., Tkáčiková, L., Naas, H.T., Cabadaj, R. and Mikula, I. (1999) Isolation of verotoxigenic Escherichia coli $\mathrm{O}_{157}$ from poultry. Folia Microbiologica, 44, 455-456. doi:10.1007/BF02903722

[16] Smerdon, W.J., Adak, G.D., O’Brien, S.J., Gilespie, I.A. and Reacher, M. (2001) General outbreaks of infectious intestinal disease linked with red meat, England and Wales, 1992-1999. Communicable Disease and Public Health, 4, 259-267.

[17] Rubio, B., Martínez, B., González-Fernández, C., GarcíaCachán, M.D., Rovira, J. and Jaim, E.I. (2006) Influence of storage period and packaging method on sliced dry cured beef "Cecina de Leon": Effects on microbiological, physicochemical and sensory quality. Meat Science, 74, 710-717. doi:10.1016/j.meatsci.2006.06.002

[18] Korkeala, H., Suortti, T. and Mäkelä, P. (1988) Ropy slime formation in vacuum-packed cooked meat products caused by homofermentative lactobacilli and a Leuconostoc species. International Journal of Food Microbiology, 7, 339-347. doi:10.1016/0168-1605(88)90060-8

[19] Von Holy, A. and Holzapfel, W.H. (1989) Spoilage of vacuum packaged processed meats by lactic acid bacteria, and economic consequences. Proceedings of the International Symposium of the World Association of Veterinary Food Hygienists Stockholm, Sweden, 185. 
[20] Tirado, C. and Schmidt, K., Eds. (2000) WHO surveillance programme for control of foodborne infections and intoxications in Europe, 7th report, 1993-1998. BGVV FAO/WHO Collaborating Centre for Research and Training in Food Hygiene and Zoonoses.

[21] Marth, E.H. (1998) Extended shelf life refrigerated foods. Food Technology, 52, 57-62.

[22] ISO 11290-2 (1998) Microbiology of food and animal feeding stuffs-Horizontal method for the detection and enumeration of Listeria monocytogenes-Part 2: Enumeration method.

[23] Allerberger, F. (2003) Listeria: Growth, phenotypic differentiation and molecular microbiology. FEMS Immunology and Medical Microbiology, 35, 183-189. doi:10.1016/S0928-8244(02)00447-9

[24] ISO 16654 (2001) Microbiology of food and animal feeding stuffs-Horizontal method for the detection of Escherichia coli $\mathrm{O} 157$.

[25] ISO 6579 (2002) Microbiology of food and animal feeding stuffs-Horizontal method for the detection of Salmonella spp.

[26] Luiz, A.F., Moreira, F.C., Corréa, E.F. and Falcão, D.P. (2004) Monitoring of the dissemination of Salmonella in the chicken Frankfurt-sausage productionline of a sausage factory in the state of São Paulo, Brazil. Brazil, Memórias do Instituto Oswaldo Cruz, Rio de Janeiro, 99, 477-480. doi:10.1590/S0074-02762004000500003

[27] Yılmaz, I., Şimşek, O. and Işıkı, M. (2002) Fatty acid composition and quality characteristics of low-fat cooked sausages made with beef and chicken meat, tomato juice and sunflower oil. Meat Science, 62, 253-258.

[28] Angelidis, A.S., Chronis, E.N., Papageoriou, D.K., Kazakis, I.I., Arsenoglou, K.C. and Stathopoulos, G.A. (2006) Nonlactic acid, contaminating microbial flora in ready-to-eat foods: A potential food-quality index. Food Microbiology, 23, 95-100. doi:10.1016/i.fm.2005.01.015

[29] ICMSF, International Commission on Microbiological Specifications for Foods (2002) Microorganisms in foods 7: Microbiological testing in food safety management. Kluwer Academic/Plenum Publishers, New York.

[30] El-Khateib, T., Abd El-Rahman, H., Hamdy, M. and Lotfi, A. (1988) Poultry meat products in Egypt "proximal chemical composition and microbiological quality". Fleischwirtsch, 68, 756-757.

[31] Zahran, D.A., Hendy, E., Bassam, A. and El-Hifnawi, H.N. (2008) Incidence and radiation sensitivity of Bacillus cereus, Listeria monocytogenes and their toxins in some chicken products. Journal of World Applied Science, 5, 182-188.

[32] Álvarez-Astorga, M., Capita, R., Alonso-Calleja, C., Moreno, B. and García-Fernández, M.D. (2002) Microbiological quality of retail chicken by-products in Spain. Meat Science, 62, 45-50. doi:10.1016/S0309-1740(01)00225-X

[33] Ismail, S.A.S., Deak, T., Abd El-Rahman, H.A., Yassien, M.A.M. and Beuchat, L.R. (2000) Presence and changes in populations of yeasts on raw and processed poultry products stored at refrigeration temperature. International
Journal of Food Microbiology, 62, 113-121. doi:10.1016/S0168-1605(00)00414-1

[34] Beuchat, L.R. and Ryu, J.H. (1997) Produce handling and processing practices. Emerging Infectious Disease Journal, 3, 459-465. doi:10.3201/eid0304.970407

[35] Nørrung, B., Andersen, J.K. and Schlundt, J. (1999) Incidence and control of Listeria monocytogenes in foods in Denmark. International Journal of Food Microbiology, 53, 195-203. doi:10.1016/S0168-1605(99)00157-9

[36] US Department of Agriculture, Food Safety and Inspection Service (USDA-FSIS) (2003) Control of Listeria monocytogenes in ready-to-eat meat and poultry products; final rule, 9 CFR 430.4. Federal Register, 68, 3420834254.

http://www.fsis.usdaov/OPPDE/rdad/FRPubs/97-013F.htm

[37] Mor-Mur, M. and Yuste, J. (2010) Emerging bacterial pathogens in meat and poultry: An overview. Food and Bioprocess Technology, 3, 24-35. doi:10.1007/s11947-009-0189-8

[38] Sirıken, B., Pamuk, S., Özakin, C., Gedikoglu, S. and Eyigör, M. (2006) A note on the incidences of Salmonella spp., Listeria spp. and Escherichia coli O157:H7 serotypes in Turkish sausage (Soudjouck). Meat Science, 72, 177-181. doi:10.1016/j.meatsci.2005.05.025

[39] Vitas, A.I. and Garcia-Jalon, V.A.I. (2004) Occurrence of Listeria monocytogenes in fresh and processed foods in Navarra (Spain). International Journal of Food Microbiology, 90, 349-356. doi:10.1016/S0168-1605(03)00314-3

[40] Noack, D.J. and Joeckel, J. (1993) Listeria monocytogenes, occurrence and significance in meat and meat products and experience with recommendations for its detection and assessment. Fleischwirtschaft, 73, 581-584.

[41] Little, C.L., Taylor, F.C., Sagoo, S.K., Gillespie, I.A., Grant, K. and McLauchlin, J. (2007) Prevalence and level of Listeria monocytogenes and other Listeria species in retail pre-packaged mixed vegetable salads in the UK. Food Microbiology, 24, 711-717. doi:10.1016/j.fm.2007.03.009

[42] Inoue, S., Nakama, A., Arai, Y., Kokubo, Y., Maruyama, T., Saito, A., Yoshida, T., Terao, T., et al. (2000) Prevalence and contamination levels of Listeria monocytogenes in retail foods in Japan. International Journal of Food Microbiology, 59, 73-77. doi:10.1016/S0168-1605(00)00284-1

[43] Franco, C.M., Quinto, E.J., Fente, C., Rodriguez-Otero, L. and Cepeda, A. (1995) Determination of the principal sources of Listeria spp. contamination in poultry meat and a poultry processing plant. Journal of Food Protection, 58, 1320-1325.

[44] Mead, G.C., Hudson, W.R. and Hinton, M.H. (1993) Microbiological survey of five poultry processing plants in the UK. British Poultry Science, 34, 497. doi:10.1080/00071669308417605

[45] Sandel, M.K. and McKillip, J.L. (2004) Virulence and recovery of Staphylococcus aureus relevant to the food industry using improvements on traditional approaches. Food Control, 15, 5-10. doi:10.1016/S0956-7135(02)00150-0 
[46] Jay, J.M., Loessner, M.J., Golden, A.A. (2005) Modern food microbiology. 7th Edition, Aspen Publishers Inc., Gaithersburg.

[47] De Roever, C. (1998) Microbiological safety evaluations and recommendations on fresh produce. Food Control, $\mathbf{9}$, 321-347. doi:10.1016/S0956-7135(98)00022-X

[48] Taulo, S., Wetlesen, A., Abrahamsen, R., Kululanga, G., Mkakosya, R. and Grimason, A. (2008) Microbiological hazard identification and exposure assessment of food prepared and served in rural households of Lungwena,
Malawi. International Journal of Food Microbiology, 125, 111-116. doi:10.1016/j.ijfoodmicro.2008.02.025

[49] Samadpour, M., Barbour, M.W., Nguyen, T., Cao, T.M., Buck, F., Depavia, G.A., Mazengia, E., Yang, P., Alfi, D., Lopes, M. and Stopforth, J.D. (2006) Incidence of enterohemorrhagic Escherichia coli, Escherichia coli O157, Salmonella, and Listeria monocytogenes in retail fresh ground beef, sprouts, and mushrooms. Journal of Food Protection, 69, 441-443. 